\title{
Defining student learning experience through blended learning
}

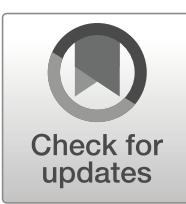

\section{Frederique Bouilheres ${ }^{1}$ (D) - Le Thi Viet Ha Le ${ }^{2} \cdot$ Scott McDonald $^{2} \cdot$ Clara Nkhoma $^{2}$. Lilibeth Jandug-Montera ${ }^{2}$}

Received: 22 May 2019 / Accepted: 4 January 2020/Published online: 18 January 2020

(C) The Author(s) 2020

\begin{abstract}
This paper aims to explore the benefits of Blended Learning towards students' learning experiences at an offshore campus of an Australian university located in Ho Chi Minh City, Vietnam. At the university campus, the Blended Learning practice in use is the displacement of content. Content displacement refers to a portion of the learning content and activities for a course being delivered online via the Learning Management System. Learning not only happens in face-to-face sessions at a given time but is extended to online spaces as well, happening anywhere at any time at students' preference. The focus of this research is its usefulness and effectiveness in promoting interactions between students and their peers, their teachers, and course materials. An online survey, which was designed based on a set of validated questions, was used to collect data from sixty-six students enrolled in eight Blended Learning courses. The analysis of the survey results provides empirical evidence to the claim that students' perception of their learning experiences at the university was beneficially impacted as a result of the Blended Learning environment in each of their classes. Specifically, factor analysis using oblique rotation method identifies a clear factor structure across survey questions, representing four dimensions of benefits: Engagement, Flexibility of learning, Online learning experience, and Self-confidence. In addition, significant differences between the clusters on these factors indicate that students vary in their responses towards the benefits of Blended Learning and their experience with a Blended Learning approach.
\end{abstract}

Keywords Blended learning $\cdot$ Expanded learning space $\cdot$ Interaction $\cdot$ Flexibility $\cdot$ Selfconfidence $\cdot$ Enriching learning experience $\cdot$ Student engagement

Frederique Bouilheres

frederique.bouilheres@nottingham.ac.uk

Extended author information available on the last page of the article 


\section{Introduction}

\subsection{Background}

The changing methods of course content delivery have long been an established topic of discussion and debate among the faculty and more particularly the academic management of universities around the globe (Hamilton and Tee 2010; Michinov and Michinov 2008). The latest focus of Learning \& Teaching departments in most universities has been the varied benefits of information and communication technologies and their potential delivery methods of the learning objectives for each course as well as the extension of the physical classroom beyond its four walls and its assignments, activities or the program itself at the institutional level (Bonk et al. 2012). These include but are not limited to, Blended Learning, the Flipped Classroom, Active Learning, Online e-Learning, and Problem Based Learning to name just a few.

These newer modes of content delivery such as Blended Learning, defined as a combination of digital and face-to-face content delivery method (Graham 2006) have been viewed by some in Higher Education as a threat to the status quo, and stand to disrupt the deep-rooted traditions of the time-honoured didactic approach of many brick and mortar institutions who have until recently, depended solely upon student tuitions in a face-to-face setting. Although seen by many as a way to bridge the gap between the traditional pedagogies and those of today's innovative thinkers, the predictions made in 2000 forecasted a $70 \%$ decline in student enrolment at universities across America from the year 2010 to 2015 (Moskal et al. 2013). These predictions, as it turned out, were not all as tragic as previously feared. The data in 2014 reported that within this period the numbers of students enrolled in US universities peaked at 21 million in 2010 and only dropped by 812,069 students within the next four years resulting in only a $4 \%$ decrease in enrolments (National Center for Educational Statistics - NCES 2014).

This particular study into the learning outcomes and experiences of students, delivered as a blended curriculum, supports the increasing global trend in the use of Blended Learning as an effective content delivery method in higher education. The delivery of this method may include one or any combination of modes to accompany the face-to-face tutorials from, using social media, to problem-solving gamification, to video-conferencing with each other or with industry participants, to role-playing activities, to virtual learning systems, to online interactive quizzes or challenges, to the multitude of simulations available online (Hamilton and Tee 2010).

This study was set in the South-East Asian campus of a large Australian university and ran over 2 semesters of a redesign phase (2016 - Semester 2 and 3) and one semester of an implementation phase (2017 - Semester 1). Eight courses were part of this project (six in the School of Business \& Management and two in the School of Science \& Technology). All these courses are core courses in their respective programs and were delivered entirely face-to-face before the implementation of the project. The courses were taught in small groups of a maximum of 30 students and involved lecturing as well as small groups or individual activities under the lecturer's monitoring (none of the courses use teaching assistants). Typically, contact hours amount to $3 \mathrm{~h}$ per week in 2 sittings. The first semester of the redesign phase involved course teams working with academic developers from the Learning \& Teaching unit (central unit within the university) to redesign their course learning pathways under a Blended Learning model. This involved displacing course 
content from the face-to-face class component to the online component as well as introducing new online activities (watching videos, completing short quizzes, discussing a topic on a discussion board, etc) to be completed before the first class of the week or in between the two classes of a given week. This also included a general wrap-up activity after the second class. All the online content and activities were hosted on the Learning Management System (LMS - Blackboard at the time). The second semester of the redesign phase involved course teams producing orientation modules for their courses. These orientation modules included a welcome video explaining what the course entails, a video or animation explaining the real world application of the course and another video or written narrative explaining what students will be able to do after they take the course. Finally, these two semesters of redesign were followed by a semester of implementation where students were taught in a Blended Learning environment which included weekly online learning pathways available on the LMS as well as face-to-face contact time.

\subsection{Aim of the study, contribution to knowledge and research questions}

The student perception of a Blended Learning model associated with this study aimed to discover and has thus far strongly supported the argument that this is a successful mode of course content delivery and as such adds to the growing body of research supporting this claim however much of the literature focuses on Western settings and thus findings may not be as relevant to developing economies and in particular those of Confucian heritage where passive and rote learning rather than active and studentcentered learning is the norm (Phelps et al. 2012).

This study hopes to contribute to knowledge of blended learning effectiveness in Confucian heritage contexts.

The overarching research question that supports this study is: "Does a Blended Learning environment increase the engagement between students and their peers, their teachers, and the course materials and is it perceived as a positive experience?"

\subsection{Structure of the paper}

Following this introduction, the article looks at the literature on student engagement with Blended Learning as well as students' perception of Blended Learning, and reviews as much of the contemporary discourse on the topic as possible. The research methodology details the approach used in this study by describing the methods and instruments used to collect the data from the students while addressing the stated hypothesis. The section discussing the results details the analysis of the data collected through the questionnaires and presents the findings that answer the study's initial research questions as well as discuss them in the light of previous studies' findings. The conclusion provides a summary of the findings and the impact they have on the discourse and the contribution they make to the current body of knowledge in this area of study. The limitations will also be discussed and reviewed for possible suggestions as to the future direction of this research.

\subsection{Literature review}

Student engagement has an important influence on the achievement and learning in higher education (Kahu 2013). It mirrors the quality of student university experience 
and is an excellent indicator of student academic success and the institution's productivity (Coates 2005; Robinson and Hullinger 2008). Coates (2005) defines student engagement as the students' interaction with learning activities and resources intended to produce authentic learning (Coates 2005). Similarly, Kuh (2009) defines student engagement as the quality of effort and involvement in productive learning activities. The measures used by the National Survey of Student Engagement (NSSE), the most extensive study on student engagement in American colleges and universities, exemplify these definitions. The NSSE measures student engagement in five aspects: (1) active and collaborative learning, (2) student interactions with faculty members, (3) level of academic challenge, (4) enriching educational experiences, (5) and supportive campus environment (Kuh 2009; Vaughan 2010). From the educators' perspective, student engagement encompasses involvement with co-curricular activities and interaction with faculty and peers (Pascarella and Terenzini 2005; Kuh 2009 cited in Junco et al. 2011). Students also share the same perspective. In Collaço's (2017) focus groups, students define student engagement as being present and attentive, interaction with peers and teachers, and enjoyment with the learning tasks. Based on these findings, Collaço (2017) characterises student engagement as consisting of behavioural, interpersonal, and affective components that need to be addressed if an authentic engagement is desired.

The rise of learning technologies presents tremendous opportunity for educators and institutions to engage students in innovative ways. When used appropriately, technology can foster student engagement (Revere and Kovach 2011) and consequently, enhance student performance and course satisfaction (Hsu and Hsieh 2011; Johnson et al. 2008). Technology mediated courses such as those delivered in purely e-learning or hybrid learning modes allow students some flexibility in engaging in their courses in their own space and time (Holsapple and Lee-Post 2006) and facilitate interactions otherwise not possible in traditional classrooms.

Learning technologies undeniably promote greater student involvement; however, these well-intended developments could also pose significant risks to learners (Holley and Oliver 2010). Technology-mediated learning is insufficient to address students' diverse problems (Johnson et al. 2008) and may disadvantage certain student populations (Chen et al. 2010). Holley and Oliver conclude that students' success in an online learning environment largely depend on the students' prior experiences, personality and personal circumstances and that for poorly equipped students, online modes of learning could pose as barriers to course participation and learning. Students' perception of their computer efficacy also had an impact on their performance (Venkatesh et al. 2014; Wu et al. 2010). Hu and Hui (2012) also noted that technology-mediated learning can unintentionally disadvantage students with low computer-self efficacy as they tend to engage in online activities less than their counterparts with high-computer efficacy. The goal for academics and institutions, therefore, is to leverage technology with differentiation to engage students with diverse backgrounds, personality and skills for them to have equal chances of succeeding in the modern classroom.

The effectiveness of learning technologies primarily depends on a number of factors (Young and Bruce 2011) including student characteristics and experiences (Holley and Oliver 2010); teaching skills and practices (Young and Bruce 2011); and other structural and psychosocial influences that impact student engagement (Kahu 2013). Elearning is effective when students are able to interact with the course content, their 
peers and their instructors (Johnson et al. 2008). Interaction is enhanced when social presence and a shared learning space that instill a sense of belongingness to a learning community are perceived by the learners (Johnson et al. 2008; Young and Bruce 2011). It is also enhanced by perceived availability of instructional, peer and technical support (Yen and Lee 2011). The perception of a shared community and availability of support stimulate social interaction and dispel the feeling of isolation caused by the lack of faceto-face social interaction in online learning (Muilenburg and Berge 2005). Furthermore, it has been argued that online platforms can never replace the physical presence and spontaneous interactions in the classroom (Chen et al. 2010; Sanders 2006). Students' desire for human touch remains (Holsapple and Lee-Post 2006) despite the advances in modern education. The issue confronting university education, therefore, is to harness the transforming power of the technology by defining and shaping learning opportunities without overlooking the value of human touch (Holsapple and Lee-Post 2006). Blended Learning, a format that integrates both the strengths of face-to-face and online learning (Garrison and Kanuka 2004), appears to have a considerable appeal to respond to this challenge.

Blended Learning in particular, helps students increase their interactions, communication skills, self-confidence, self-awareness, as well as encourage discussion and collaboration not only with their lecturers but also with their peer classmates and course materials leading to an overall positive experience reported by the students (Kumar 2009; Richardson and Ice 2010; Chan et al. 2016) thus becoming more active in their learning (Kumar 2010) and creating a more interesting and engaging learning process. This may be accomplished by introducing modern technologies and tools to enhance the learning activities in offering courses that many students in this digital age already feel comfortable using and thus be more willing to participate and collaborate with others in such e-tivities supporting a constructivist approach (Hoic-Bozic et al. 2016; Cummings et al. 2017).

To achieve these benefits, however, it is crucial to understand the learner's perception of Blended Learning as these perceptions can be used in designing a more detailed and realistic strategy for meeting the student's educational needs (Kim 2012). A study conducted by $\mathrm{Wu}$ et al. (2010) postulated that performance expectations and the learning environment determined the learning satisfaction of students from a Blended Learning environment. Students view flexibility of access as an important element of Blended Learning however, others reported that Blended Learning reduced their interaction with their teachers and their peers (Kim 2012). Some students may even feel isolated by Blended Learning if teachers do not promote social networking and community building (Donnelly 2010) which could lead to reduced motivation to learn (Osguthorpe and Graham 2003). A recent meta-analysis (Castro 2019) conducted a comprehensive review of 45 articles on this subject and identified five enabling or hindering factors being opportunities, barriers, drivers, effects, and challenges that affect Blended Learning as a system as well as specific tools or technologies that affect the learning activities within the classroom. The teachers' effective use of technologies (computers, electronic devices, and LMS software) and the capabilities of each play a role in how the Blended Learning approach is viewed by the learners.

Table 1 below includes a summary of the benefits of blended learning from the students' perspective.

Apart from the technology, it is important to have a learning environment that promotes peer to peer, and peer to instructor collaboration (Johnson et al. 2008). 
Table 1 Benefits of blended learning

\begin{tabular}{ll}
\hline Themes & Reference \\
\hline Personalization/Individual learning path & $\begin{array}{c}\text { Garrison and Arbaugh 2007; McLoughlin and } \\
\text { Lee 2008; Danker 2015; Khawaja et al. 2013. }\end{array}$ \\
Learner centered & Garrison and Arbaugh 2007; McLoughlin and Lee 2008 \\
Enhancing learners motivation and engagement & Garrison and Arbaugh 2007; Littlejohn et al. 2012. \\
Participation & McLoughlin and Lee 2008. \\
Self-paced learning & Danker 2015. \\
Flexibility & Khawaja et al. 2013. \\
Improvement in learning outcomes/performance & Khawaja et al. 2013; Hsieh and Wu 2013; \\
Hoic-Bozic et al. 2016. \\
Critical thinking skills & Yang et al. 2014. \\
Peer support/peer collaboration & El-Ghareeb and Riad 2011; Li and Chen 2009. \\
One-on-one tutoring & El-Ghareeb and Riad 2011. \\
Group tutoring & Kleinert et al. 2015. \\
Feedback & Francis and Shannon 2013. \\
\hline
\end{tabular}

Overall, studies have collectively found that students generally have a positive perception of Blended Learning (Ugur et al. 2011). Students like Blended Learning because online learning allows them to learn repetitively and also review course content (Kim 2012). This study concurred with Harrington and Loffredo (2010) who found that introverted learners preferred Blended Learning. Women and extraverted learners had a lower preference for online learning (Kim 2012) and thus enrolled in more face-to-face courses. Males preferred to learn individually whilst females preferred group work (Venkatesh et al. 2014). Additionally, students are more likely to adopt technology if they have committed a lot of time learning that technology and they can make a connection with industry for their future careers (Venkatesh et al. 2014). Consequently, it is important to pay attention to nurturing social interaction and fostering an effective learning environment when designing Blended Learning (Boelens et al. 2017).

\section{Research methods and methodology}

\subsection{Project model and theoretical framework}

This project and study adopted a Blended Learning model as defined by Graham (2006), which combines face-to-face and online, and computer-mediated instruction.

To redesign Blended Learning courses (modules or units), the project on which this study is based used the RASE (Resources-Activity-Support-Evaluation) learning design model (Churchill 2006). In this model, units of interactivity (where students engage with each other and course material, learning objects, and other tools), and applications of Web 2.0 and other social media, and educational technologies are central. There has been a tendency for new technologies to be added to existing curriculum design and learning and teaching practice in an ad hoc, isolated manner, 
rather than as part of an overarching learning design which incorporates both new technologies and traditional techniques and understanding of pedagogic principles and practice (Churchill et al. 2013). The central idea behind the RASE model is that 'content' resources are not sufficient for the full achievement of the learning outcomes; it is also important to plan for activity, support and evaluation from both lecturers and peers. The model builds upon important theoretical work and concepts such as a constructivist learning environment (Jonassen 1999), engaged learning (Dwyer et al. 1985-1998), problem-based learning (Savery and Duffy 1995), technology-based learning environments (Wang and Hannafin 2005), interactive learning environments (Oliver et al. 2002), and situated learning (Brown et al. 1989). The figure below is a visual summary of the RASE pedagogical model (Fig. 1).

This project involved teaching staff across the courses to use the RASE model and to design learning experiences that have several consistent elements and principles. These include, but are not limited to, a consistent learning management system experience, content displacement (Blended Learning), course orientation modules that are fully online, cross-course learning activities. Key principles for the learning design are:

- Curriculum is designed so that learning opportunities span the digital and physical environment, inside and outside the classroom;

- Digital and physical learning environments are inclusive;

- Increased interaction between lecturers and students, among students, and students with course materials.

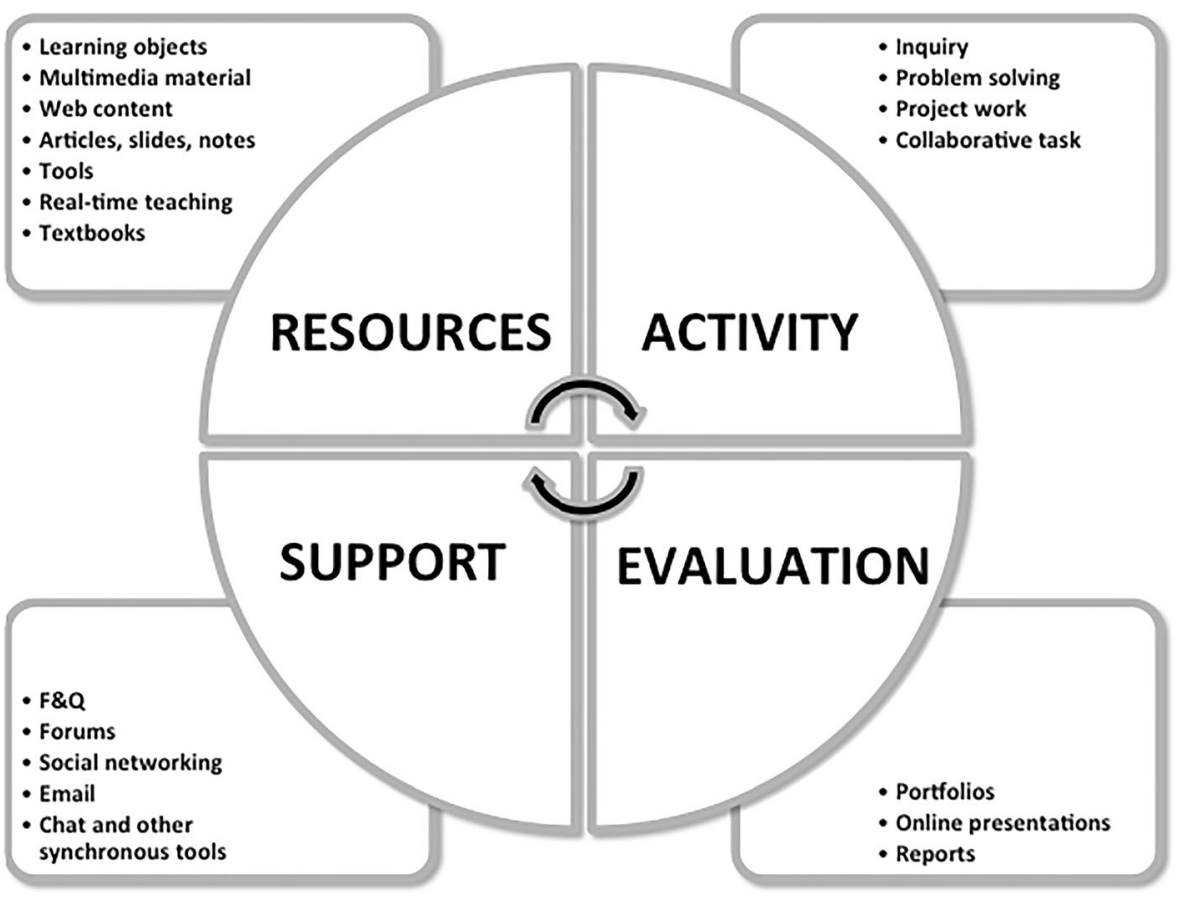

Fig. 1 RASE pedagogical model (Churchill 2006) 


\subsection{Research methodology and participants}

This study involved the collection of quantitative data from students, which utilises survey methodology. During the first implementation semester, the students in each of the respective courses were surveyed using the questionnaire that is detailed in the following section. They were typically second year students with the overwhelming majority of students being of Confucian-learning heritage.

Participants of the survey were recruited from all the courses that were part of the project. Students in these courses were invited to participate in the study by way of invitation through an online survey on Qualtrics with a link posted on the LMS of each course.

To address the research questions, the data that was collected in the quantitative phase of the project was trying to address the following areas and was based on the following references:

- Blended Course Student Survey (Student Next Generation Learning Challenges (NGLC) Survey, University of Central Florida (UCF) and the American Association of State Colleges and Universities (AASCU) (UCF and AASCU 2017);

- Student Approaches to Learning - deep and surface (Biggs 1987).

\subsection{Research instrument and data collection technique}

Data were collected during Semester 1, 2017 from a primary data source. The primary data source is a questionnaire which assesses the level of interaction between students, students and teachers, and with the course material as a result of the implementation of a Blended Learning approach.

Nine out of fifteen questions were developed based on the questions in Blended Course Student Survey by UCF and AASCU (2017) and measured four dimensions of students' online learning experiences: (1) convenience and flexibility of online learning in comparison with in-class learning (Question 9 and 10); (2) clarity of online course requirements (Question 15); (3) quantity and quality of students' interaction with lecturers, with other students, and with learning materials (Questions 2, 11, 12, 13 and 14); and (4) students' attitudes and engagement with learning (Question 5).

The remaining six questions referred to Student Approaches to Learning survey by Biggs (1987) and investigated the importance of online learning in supporting in-class learning and developing deep study approaches for students. Questions 1, 4 and 7 were concerned about the content consistency between online learning and in-class learning; while Questions 3, 6 and 8 asked whether online learning motivated students to dig deeper into topics and apply them in class. Note that the questions were slightly reworded to better reflect the learning environment at the university, particularly the use of Blackboard as the LMS (Biggs' survey was developed before the advent of the Internet and thus did not include matters related to online learning) as well as to fit the scale of measurement. However using previously tested questionnaires, albeit in a modified way, ensured the validity of the questionnaire.

The full questionnaire is in Table 2 below.

Additionally, students were asked if they had taken any of the business foundation courses in previous semesters as these courses had been redesigned the year before as part of a similar project and a comparison between those who did and those who did not 
Table 2 Questionnaire

No Question

1 Activities I completed in Blackboard prepared me for in-class learning.

2 Online materials help me gain a clearer understanding of the subject.

3 Understanding online materials helped me move the topics further in class.

4 I feel more confident coming to the class with certain knowledge in advance by studying online.

5 My online experiences helped me engage actively in my learning.

6 With a certain understanding before coming to class, I'm more likely to ask questions in the class.

7 My online learning experience using Blackboard were well-integrated with my face-to-face learning.

8 Blackboard materials provided me with opportunities to apply or practice what I learned during in-class sessions.

9 With online materials provided on Blackboard, I can study anytime, anywhere I can.

10 With online materials provided on Blackboard, I can study at my own pace.

11 With this Blended Learning approach, I interact more with other students inside and outside of classroom

12 With this Blended Learning approach, the quality of my interaction inside and outside of classroom with other students is much better

13 With this Blended Learning approach, I interact more with my lecturers inside and outside of classroom

14 With this Blended Learning approach, the quality of my interaction with my lecturers inside and outside of classroom is much better

15 It was clear about the expectation of lecturers in terms of students' participation and output from studying online.

take these courses could shed some light on whether having a prior Blended Learning experience improves the students experience with the course overall.

\subsection{Hypotheses}

Using statistical analysis of survey results and based on the findings of the literature review above, the study expects to provide evidence to the following hypotheses:

- Hypothesis 1: a Blended Learning environment increases the engagement between students and their peers;

- Hypothesis 2: a Blended Learning environment increases the engagement between students and their teachers;

- Hypothesis 3: a Blended Learning environment increases the engagement between students and the course materials.

- Hypothesis 4: a Blended Learning environment increases the flexibility of learning

- Hypothesis 5: a Blended Learning environment constitutes a positive online learning experience.

- Hypothesis 6: a Blended Learning environment increases students self-confidence.

Testing these hypotheses will provide an answer to the research question that supports this study: "Does a Blended Learning environment increase the engagement between these students and their peers, their teachers, and the course materials and is it perceived as a positive experience?" 


\section{Results and discussion of results}

This section examines students' responses to a survey of fifteen questions about their Blended Learning experience. The sample size is sixty-six (response rate: $8 \%$ ) with $68 \%$ of students having prior Blended Learning experience. These are mainly second year students who have finished their eight foundation courses with the same Blended Learning approach. This survey uses a 4 point Likert scale with " 1 " being Totally Disagree, " 2 " being Disagree, " 3 " being Agree, and " 4 " being Totally Agree.

Firstly, Table 3 provides the descriptive statistics of responses to all questions which shows that students are positive about online materials found on Blackboard (the LMS system used in this study) providing them with more flexibility to study (Question 10), helping them understand the face-to-face session better (Questions 3,4 and 9).

\subsection{Factor analysis}

Factor analysis using an oblique rotation method is used to identify a simple structure, by eliminating items (questions) with low loadings (less than 0.5) and/or cross-loadings between factors. Among the fifteen questions, fourteen questions (excluding Question 15) with a clear factor structure across four factors are identified. The four factors are labelled

Table 3 Descriptive statistics for all questions

\begin{tabular}{|c|c|c|c|}
\hline No & Question & Mean & SD \\
\hline 10 & With online materials provided on Blackboard, I can study at my own pace. & 3.2121 & 0.62055 \\
\hline 9 & With online materials provided on Blackboard, I can study anytime, anywhere I can. & 3.1667 & 0.73554 \\
\hline 3 & Understanding online materials helped me move the topics further in class. & 3.1364 & 0.67679 \\
\hline 4 & $\begin{array}{l}\text { I feel more confident coming to the class with certain knowledge in advance by } \\
\text { studying online. }\end{array}$ & 3.1212 & 0.7749 \\
\hline 2 & Online materials help me gain a clearer understanding of the subject. & 3.0758 & 0.7506 \\
\hline 6 & $\begin{array}{l}\text { With a certain understanding before coming to class, I'm more likely to ask questions } \\
\text { in the class. }\end{array}$ & 3.0758 & 0.72982 \\
\hline 15 & $\begin{array}{l}\text { It was clear about the expectation of lecturers in terms of students' participation and } \\
\text { output from studying online. }\end{array}$ & 3.0758 & 0.72982 \\
\hline 8 & $\begin{array}{l}\text { Blackboard materials provided me with opportunities to apply or practice what I } \\
\text { learned during in-class sessions. }\end{array}$ & 03 & 26 \\
\hline 5 & My online experiences helped me engage actively in my learning. & 3 & 0.70165 \\
\hline 1 & Activities I completed in Blackboard prepared me for in-class learning. & 2.9848 & 0.61999 \\
\hline 14 & $\begin{array}{l}\text { With this Blended Learning approach, the quality of my interaction with my lecturers } \\
\text { inside and outside of classroom is much better }\end{array}$ & 2.9545 & 0.66638 \\
\hline 13 & $\begin{array}{l}\text { With this Blended Learning approach, I interact more with my lecturers inside and } \\
\text { outside of classroom }\end{array}$ & 2.9538 & 0.64758 \\
\hline 7 & $\begin{array}{l}\text { My online learning experience using Blackboard were well-integrated with my } \\
\text { face-to-face learning. }\end{array}$ & 2.8939 & 0.76719 \\
\hline 12 & $\begin{array}{l}\text { With this Blended Learning approach, the quality of my interaction inside and outside } \\
\text { of classroom with other students is much better }\end{array}$ & 2.8485 & 0.80846 \\
\hline 11 & $\begin{array}{l}\text { With this Blended Learning approach, I interact more with other students inside and } \\
\text { outside of classroom }\end{array}$ & 2.8 & 0.81394 \\
\hline
\end{tabular}


Engagement, Flexibility of learning, Online learning experience, and Self-confidence. The four identified factors show that the total percentage of variation explained is $78.977 \%$. The Table 12 in the Appendix 1 shows the items and factor loadings.

Table 4 shows the result of the Kaiser-Meyer-Olkin (KMO) and Bartlett's test, the KMO coefficient (measure of sampling adequacy) is 0.806 and the Bartlett's test of Sphericity shows significant result, which means that this factor analysis is useful for this data set.

\subsection{Reliability test}

Reliability test is conducted using Cronbach's alpha with results ranging from 0.713 (Self-confidence), 0.766 (Flexibility of learning), 0.905 (Online learning experience), and 0.913 (Engagement). These results suggest that the items in each factor have relatively high internal consistency or can be used to measure the same underlying meaning of the factors, which again confirms the adequacy of the factor analysis.

\subsection{Descriptive statistics for each factor}

As a result of the factor analysis, the descriptive statistics and frequency analysis are provided in groups of questions which are considered to be similar in nature. This shows a more detailed picture of the students' experience and perception toward Blended Learning.

Questions 7, 11, 12, 13, and 14 in Table 5 focus on the quantity and quality of the interaction between students and their lecturers as well as their peers inside and outside of the classroom; and the integration of online and face-to-face learning.

Questions 7,13 and 14 show a positive experience where the percentage of Agree and Totally Agree are more than $80 \%$. This confirms previous findings around increased engagement with teaching staff (Cochrane and Bateman 2010; Chen et al. 2010). However, Questions 11 and 12 with a higher percentage of Disagree and Totally Disagree and relatively lower mean and higher standard deviation compared to the other questions, suggest that students consider their interactions with student peers to be less frequent and of a lower quality. This finding would tend to confirm previous studies which have found Blended Learning to lack social connectivity (McLoughlin and Lee 2010) or even lead to dissociation from peers (Reese 2015) but contradicts Cochrane and Bateman (2010) who found an enhanced engagement between students.

Questions 9 and 10 focus on the Flexibility of learning. The results shown in Table 6 suggest that students tend to see the benefit of the online platform where they can study anywhere, at any time (84.3\% Agree or Totally Agree) and especially at their own pace

Table 4 KMO and Bartlett's test

\begin{tabular}{|c|c|c|}
\hline \multicolumn{2}{|c|}{ Kaiser-Meyer-Olkin Measure of Sampling Adequacy } & .806 \\
\hline \multirow[t]{3}{*}{ Bartlett's Test of Sphericity } & Approx. Chi-Square & 762.865 \\
\hline & Df & 105 \\
\hline & $\mathrm{Sig}$ & .000 \\
\hline
\end{tabular}


Table 5 Descriptive statistics for questions focusing on student engagement with peers, lecturers and material

\begin{tabular}{|c|c|c|c|c|c|c|c|}
\hline \multirow[t]{2}{*}{ No } & \multirow[t]{2}{*}{ Question } & \multirow[t]{2}{*}{ Mean } & \multirow[t]{2}{*}{ S.D. } & \multicolumn{4}{|c|}{ Likert scale response $(\%)$} \\
\hline & & & & $\begin{array}{l}\text { Totally } \\
\text { Disagree }\end{array}$ & Disagree & Agree & $\begin{array}{l}\text { Totally } \\
\text { Agree }\end{array}$ \\
\hline 11 & $\begin{array}{l}\text { With this Blended Learning approach, I interact } \\
\text { more with other students inside and outside } \\
\text { of classroom. }\end{array}$ & 2.8000 & .81394 & 6.2 & 26.2 & 49.2 & 18.5 \\
\hline 12 & $\begin{array}{l}\text { With this Blended Learning approach, the } \\
\text { quality of my interaction inside and outside } \\
\text { of classroom with other students is much } \\
\text { better. }\end{array}$ & 2.8485 & .80846 & 7.6 & 18.2 & 56.1 & 18.2 \\
\hline 14 & $\begin{array}{l}\text { With this Blended Learning approach, the } \\
\text { quality of my interaction with my lecturers } \\
\text { inside and outside of classroom is much } \\
\text { better. }\end{array}$ & 2.9545 & .66638 & 3 & 15.2 & 65.2 & 16.7 \\
\hline 7 & $\begin{array}{l}\text { My online learning experience using } \\
\text { Blackboard were well-integrated with my } \\
\text { face-to-face learning. }\end{array}$ & 2.8939 & .76719 & 7.6 & 12.1 & 63.6 & 16.7 \\
\hline 13 & $\begin{array}{l}\text { With this Blended Learning approach, I interact } \\
\text { more with my lecturers inside and outside of } \\
\text { classroom. }\end{array}$ & 2.9538 & .64785 & 1.5 & 18.5 & 63.1 & 16.9 \\
\hline
\end{tabular}

(92.4\% Agree or Totally Agree). These findings echo Kim's (2012) where students favoured learning flexibility afforded by Blended Learning.

Questions 1, 2, 3, 5 and 8 in Table 7 focus on Online learning experience (enriching educational experience). Students' responses are generally positive regarding the benefit of using materials on an LMS to better prepare for, understand and engage with inclass activities (between $83 \%$ and $93 \%$ Agree or Totally Agree). These findings confirm the general consensus around the benefits of Blended Learning as a learning experience (Cochrane and Bateman 2010; Kumar 2010; Vaughan 2010).

Questions 4 and 6 in Table 8 focus on improving students' self-confidence and participation in class. Students are positive about online studying helping them to be confident about engaging with in-class activities which echoes previous studies around the benefits of Blended Learning on self-confidence and collaboration (Kumar 2009; Richardson and Ice 2010; Chan et al. 2016).

Table 6 Descriptive statistics for questions focusing on the flexibility of learning

\begin{tabular}{|c|c|c|c|c|c|c|c|}
\hline \multirow[t]{2}{*}{ No } & \multirow[t]{2}{*}{ Question } & \multirow[t]{2}{*}{ Mean } & \multirow[t]{2}{*}{ S.D. } & \multicolumn{4}{|c|}{ Likert scale response $(\%)$} \\
\hline & & & & $\begin{array}{l}\text { Totally } \\
\text { Disagree }\end{array}$ & Disagree & Agree & $\begin{array}{l}\text { Totally } \\
\text { Agree }\end{array}$ \\
\hline 9 & $\begin{array}{l}\text { With online materials provided on Blackboard, } \\
\text { I can study anytime, anywhere I can. }\end{array}$ & 3.1667 & .73554 & 1.5 & 15.2 & 48.5 & 35.8 \\
\hline 10 & $\begin{array}{l}\text { With online materials provided on Blackboard, } \\
\text { I can study at my own pace. }\end{array}$ & 3.2121 & .62055 & 1.5 & 6.1 & 62.1 & 30.3 \\
\hline
\end{tabular}


Table 7 Descriptive statistics for questions focusing on the online learning experience (enriching educational experience)

\begin{tabular}{|c|c|c|c|c|c|c|c|}
\hline \multirow[t]{2}{*}{ No } & \multirow[t]{2}{*}{ Question } & \multirow[t]{2}{*}{ Mean } & \multirow[t]{2}{*}{ S.D. } & \multicolumn{4}{|c|}{ Likert scale response $(\%)$} \\
\hline & & & & $\begin{array}{l}\text { Totally } \\
\text { Disagree }\end{array}$ & Disagree & Agree & $\begin{array}{l}\text { Totally } \\
\text { Agree }\end{array}$ \\
\hline 2 & $\begin{array}{l}\text { Online materials help me gain a clearer } \\
\text { understanding of the subject. }\end{array}$ & 3.0758 & .75060 & 4.5 & 10.6 & 57.6 & 27.3 \\
\hline 1 & $\begin{array}{l}\text { Activities I completed in Blackboard prepared } \\
\text { me for in-class learning. }\end{array}$ & 2.9848 & 61999 & 3 & 10.3 & 71.2 & 15.2 \\
\hline 3 & $\begin{array}{l}\text { Understanding online materials helped me } \\
\text { move the topics further in class. }\end{array}$ & 3.1364 & .67679 & 3 & 7.6 & 62.1 & 27.3 \\
\hline 8 & $\begin{array}{l}\text { Blackboard materials provided me with } \\
\text { opportunities to apply or practice what I } \\
\text { learned during in-class sessions. }\end{array}$ & 3.0303 & .72260 & 4.5 & 10.6 & 62.1 & 22.7 \\
\hline 5 & $\begin{array}{l}\text { My online experiences help me engage actively } \\
\text { in my learning. }\end{array}$ & 3.0000 & .70165 & 6.1 & 6.1 & 69.7 & 18.2 \\
\hline
\end{tabular}

\subsection{Correlation analysis}

Table 9 presents the results of internal consistency tests between the different factors.

Correlation analysis with alpha $=0.01$ as level of significance indicates that there is a significant correlation among the factors ranging from 0.389 to 0.709 and thus that the results are reliable. The results show that the constructs are overlapping to a certain extent. For example, a positive online learning experience may be due to a high interaction with the lecturer or peers in the course $(\mathrm{r}=0.709)$.

\subsection{Cluster analysis}

Cluster analysis is used to identify subgroups of students who vary systematically according to their responses to questions about their Blended Learning experience, specifically about the level of Engagement, Online learning experience, Flexibility of

Table 8 Descriptive statistics for questions focusing on improving students' self-confidence

\begin{tabular}{|c|c|c|c|c|c|c|c|}
\hline \multirow[t]{2}{*}{ No } & \multirow[t]{2}{*}{ Question } & \multirow[t]{2}{*}{ Mean } & \multirow[t]{2}{*}{ S.D. } & \multicolumn{4}{|c|}{ Likert scale response $(\%)$} \\
\hline & & & & $\begin{array}{l}\text { Totally } \\
\text { Disagree }\end{array}$ & Disagree & Agree & Totally Agree \\
\hline 4 & $\begin{array}{l}\text { I feel more confident coming to the class } \\
\text { with certain knowledge in advance } \\
\text { by studying online. }\end{array}$ & 3.1212 & .77490 & 3 & 15.2 & 48.5 & 33.3 \\
\hline 6 & $\begin{array}{l}\text { With a certain understanding before } \\
\text { coming to class, I'm more likely to } \\
\text { ask questions in the class. }\end{array}$ & 3.0758 & .72982 & 3 & 13.6 & 56.1 & 27.3 \\
\hline
\end{tabular}


Table 9 Correlations between engagement, online experience, flexibility of learning, and self-confidence

\begin{tabular}{|c|c|c|c|c|}
\hline & Interaction/Integration & $\begin{array}{l}\text { Online } \\
\text { experience }\end{array}$ & Flexibility of learning & Self confidence \\
\hline 1. Interaction/Integration & 1 & & & \\
\hline 2. Online experience & $.709 * *$ & 1 & & \\
\hline 3. Flexibility of learning & $.511 * *$ & $.4^{* *}$ & 1 & \\
\hline 4. Self-confidence & $.509 * *$ & $.447 * *$ & $.389 * *$ & 1 \\
\hline $\begin{array}{l}* * \text {. Correlation is significant at } \\
\text { the } 0.01 \text { level (2-tailed) }\end{array}$ & & & & \\
\hline
\end{tabular}

learning, and Self-confidence. Using a two-step cluster analysis, the students are categorized in four clusters which are the best representations of similarities and dissimilarities among groups of students. Table 10 provides the distribution of observations in each cluster or the number of observations in each cluster.

The results of the cluster analysis in Table 10 show that, Cluster 1, which accounts for $34.8 \%$ of the total number of respondents, can be characterised as a group of students who have relatively consistent and fairly high scores for all four factors (ranging from 2.96 to 3.15); the group of students in Cluster 2 accounts for 33.3\% and have consistently high scores (ranging from 3.4 to 3.77); Cluster 3 accounts for $16.7 \%$ and can be characterised with students having relatively low scores, especially on Engagement (mean =1.95); Cluster 4 accounts for $15.2 \%$ and is characterised with students having relatively high scores on Online learning experience and Flexibility of learning, but relatively low on Self-confidence and Engagement.

The differences between the clusters on the above factors are all statistically significant, which means that students vary in their responses toward the benefit of Blended Learning and their experience with a Blended Learning approach confirming previous literature (Kim 2012) showing mixed results regarding students' experience with Blended Learning with some benefits like Flexibility of learning being counterbalanced by disadvantages such as lack of engagement with peers or teachers.

Table 11 shows the results for the ANOVA comparing the four factors between students who were experiencing Blended Learning for the first time and those who had a prior experience.

Table 10 Descriptive statistics for responses on blended learning experience by cluster membership

\begin{tabular}{|c|c|c|c|c|c|c|c|c|}
\hline \multirow[t]{2}{*}{ Factor } & \multicolumn{2}{|c|}{ Cluster $1(n=23)$} & \multicolumn{2}{|c|}{ Cluster $2(n=22)$} & \multicolumn{2}{|c|}{ Cluster $3(n=11)$} & \multicolumn{2}{|c|}{ Cluster $4(n=10)$} \\
\hline & Mean & S.D. & Mean & S.D. & Mean & S.D & Mean & S.D \\
\hline Engagement & 2.97 & .10962 & 3.4 & .49677 & 1.95 & .51452 & 2.60 & .51452 \\
\hline Online experience & 3.03 & .10962 & 3.54 & .36716 & 2.13 & .64667 & 3.02 & .64667 \\
\hline Flexibility of learning & 2.96 & .29822 & 3.77 & .33549 & 2.64 & .80904 & 3.05 & .80904 \\
\hline Self-confidence & 3.15 & .31748 & 3.64 & .38365 & 2.77 & .68424 & 2.15 & .68424 \\
\hline
\end{tabular}


Table 11 Analysis of variance - ANOVA (of factors)

\begin{tabular}{llrrrrr}
\hline & Sum of Squares & df & Mean Square & F & Sig. \\
\hline Engagement & Between Groups & 16.561 & 3 & 5.520 & 37.299 & .000 \\
& Within Groups & 9.176 & 62 & .148 & & \\
& Total & 25.738 & 65 & & & \\
Online experience & Between Groups & 14.591 & 3 & 4.864 & 36.804 & .000 \\
& Within Groups & 8.193 & 62 & .132 & & \\
Flexibility of learning & Total & 22.784 & 65 & & & \\
& Between Groups & 12.292 & 3 & 4.097 & 21.011 & .000 \\
& Within Groups & 12.091 & 62 & .195 & & \\
Self-confidence & Total & 24.383 & 65 & & & \\
& Between Groups & 16.595 & 3 & 5.532 & 28.544 & .000 \\
& Within Groups & 12.015 & 62 & .194 & & \\
& Total & 28.610 & 65 & & & \\
\hline
\end{tabular}

The results show that students have significantly different experiences of a Blended Learning model in terms of Engagement, Online experience, Flexibility of learning and Self-Confidence depending on whether they had a prior Blended Learning experience or not.

However, when we test for differences between students who had a prior Blended Learning experience and students who were introduced to Blended Learning for the first time at the question (as opposed to factor) level, the t-test shows no significant results $(p>0.05)$ which is consistent with some literature (Kim 2012) about mixed findings of the impact of Blended Learning on students' experience or may indicate that the benefits of Blended Learning are acquired from the first exposure.

\section{Conclusion}

\subsection{Summary of findings and contribution to knowledge}

The research into Blended Learning is not new. The research conducted in this study seeks to approach the subject from the standpoint of understanding the impact of student engagement and experiences delivered through a Blended Learning model used at the university. This type of content delivery is very new to Vietnam and therefore the perception of this innovative approach in a culture that had traditionally followed a rigid teacher-centered didactic structure, is unknown at this stage.

This study was conducted over the last two (2) semesters of 2016 as well as the first semester of 2017, and included eight (8) different student groups and subjects across the schools of Business \& Management as well as Science \& Technology within the university. The students surveyed for this research were second year undergraduate students. Each student participant was asked about their perceived Blended Learning experience and answered fifteen (15) 
questions pertaining to those experiences and outcomes of using the Blended Learning format in their respective courses.

The results of the study support the claim that student perception of their learning experiences as well as their engagement with peers, lecturers and content at the university were beneficially impacted as a result of the Blended Learning environment. These findings support the need to move away from the traditional pedagogical practices currently modelled in the national school programs in Vietnam, and towards a broader learning spectrum to include not only a teacher-student interaction, but a peer interaction as well as a digital online interaction component, however given the somehow mixed nature of the results and in particular how this new environment affects groups of students differently, further research is needed regarding how students make use of the Blended Learning environment and in particular the online component. These findings are important as they run counter to expectations related to passive learning in Confucian cultures and the idea that students in these cultures like to be 'talked at', prefer to listen rather than interact with peers or instructors and adopt surface learning approaches to learning.

\subsection{Limitations}

Due to the numbers of student surveys conducted by the university each semester, the initial limitation is the ability to survey future classes to check for a continuous positive perception of Blended Learning (university policy strictly limits the number of surveys the students are subject to every semester). Another limitation is that this study did not investigate the effect of the different types of online activities or learning materials that the students were exposed to. And in order to reduce the length of the survey, it did not include any demographic data questions which prevents the research on investigating the differences in the gender, age, etc.

\subsection{Future research}

Further studies may find that some selected combinations of activities in Blended Learning along with the face-to-face delivery of the content are more effective or perhaps more beneficial than other models. Deeper studies are needed to determine the appropriateness and effectiveness of each individual activity and/or learning material used in the delivery of every program having implemented a Blended Learning model.

\footnotetext{
Abbreviations RASE, Resources - Activity - Support - Evaluation; NCES, National Center for Educational Statistics; NSSE, National Survey of Student Engagement; LMS, Learning Management System; $N G L C$, Next Generation Learning Challenges; $U C F$, University of Central Florida; $A A S C U$, American Association of State Colleges and Universities; KMO, Kaiser-Meyer-Olkin (test); ANOVA, Analysis of Variance
} 


\section{Appendix 1}

Table 12 Factor analysis structure for blended learning experience

\begin{tabular}{llll}
\hline Items & Factor & & \\
\cline { 2 - 3 } & $\begin{array}{l}\text { Interaction/ Flexibility Online } \\
\text { Integration }\end{array}$ & $\begin{array}{l}\text { Self } \\
\text { of learning experience confidence }\end{array}$ \\
\hline
\end{tabular}

11. With this Blended Learning approach, I interact more .902 with other students inside and outside of classroom.

12. With this Blended Learning approach, the quality of .865 my interaction inside and outside of classroom with other students is much better.

14. With this Blended Learning approach, the quality of .708 my interaction with my lecturers inside and outside of classroom is much better.

7. My online learning experience using Blackboard were well-integrated with my face-to-face learning.

13. With this Blended Learning approach, I interact more .581 with my lecturers inside and outside of classroom.

9. With online materials provided on Blackboard, I can study anytime, anywhere I can.

10. With online materials provided on Blackboard, I can study at my own pace.

2. Online materials help me gain a clearer understanding of the subject.

1. Activities I completed in Blackboard prepared me for in-class learning.

3. Understanding online materials helped me move the topics further in class.

8. Blackboard materials provided me with opportunities to apply or practice what I learned during in-class sessions.

5. My online experiences help me engaged actively in my learning.

4. I feel more confident coming to the class with certain knowledge in advance by studying online.

6. With a certain understanding before coming to class, I'm more likely to ask questions in the class. 
Open Access This article is licensed under a Creative Commons Attribution 4.0 International License, which permits use, sharing, adaptation, distribution and reproduction in any medium or format, as long as you give appropriate credit to the original author(s) and the source, provide a link to the Creative Commons licence, and indicate if changes were made. The images or other third party material in this article are included in the article's Creative Commons licence, unless indicated otherwise in a credit line to the material. If material is not included in the article's Creative Commons licence and your intended use is not permitted by statutory regulation or exceeds the permitted use, you will need to obtain permission directly from the copyright holder. To view a copy of this licence, visit http://creativecommons.org/licenses/by/4.0/.

\section{References}

Biggs, J. B. (1987). Student approaches to learning and studying. Research monograph. Hawthorn: Australian Council for Educational Research Ltd.

Boelens, R., De Wever, B., \& Voet, M. (2017). Four key challenges to the design of blended learning: A systematic literature review. Educational Research Review, 22, 1-18. https://doi.org/10.1016/j. edurev.2017.06.001.

Bonk, C. J., \& Graham, C. R. (2012). The handbook of blended learning: Global perspectives, local designs. John Wiley \& Sons.

Brown, J. S., Collins, A., \& Duguid, P. (1989). Situated cognition and the culture of learning. Educational Researcher, 18(1), 32-42.

Castro, R. (2019). Blended learning in higher education: Trends and capabilities. Education and Information Technologies, 24(4), 2523-2546.

Chan, Y. F., Narasuman, S., Dalim, S. F., Sidhu, G. K., \& Lee, L. F. (2016). Blended learning as a conduit for inquiry-based instruction, active learning, formative assessment and its impact on students' learning outcomes in higher education. :74-78.

Chen, P. S. D., Lambert, A. D., \& Guidry, K. R. (2010). Engaging online learners: The impact of web-based learning technology on college student engagement. Computers \& Education, 54(4), 1222-1232.

Churchill, D. (2006). Teachers' private theories and their design of technology-based learning. British Journal of Educational Technology, 37(4), 559-576.

Churchill, D., King, M., Webster, B., \& Fox, B. (2013). Integrating learning design, interactivity, and technology. In H. Carter, M. Gosper \& J.Hedberg (Eds.), Proceedings of 30th Australian Society for Computers in Learning in Tertiary Education Conference (ASCILITE) (pp. 139-143). Sydney, Australia.

Coates, H. (2005). The value of student engagement for higher education quality assurance. Quality in Higher Education, 11(1), 25-36.

Cochrane, T., \& Bateman, R. (2010). Smartphones give you wings: Pedagogical affordances of mobile web 2.0. Australasian Journal of Educational Technology, 26(1). https://doi.org/10.14742/ajet.1098

Collaço, C. M. (2017). Increasing student engagement in higher education. Journal of Higher Education Theory and Practice; West Palm Beach, 17(4), 40-47.

Cummings, C., Mason, D., Shelton, K., \& Baur, K. (2017). Active learning strategies for online and blended learning environments. In Flipped Instruction: Breakthroughs in Research and Practice (pp. 88-114). IGI Global.

Danker, B. (2015). Using flipped classroom approach to explore deep learning in large classrooms.IAFOR. Journal of Education, 3(1), 171-186.

Donnelly, R. (2010). Harmonizing technology with interaction in blended problem-based learning. Computers \& Education, 54(2), 350-359.

Dwyer, D. C., Ringstaff, C., Haymore, J., \& Sandholtz, P. (1985-1998). Apple classrooms of tomorrow. Educational Leadership.

El-Ghareeb, H., \& Riad, A. (2011). Empowering adaptive lectures through activation of intelligent and web 2.0 technologies. International Journal on E-Learning, 10(4), 365-391.

Francis, R., \& Shannon, S. J. (2013). Engaging with blended learning to improve students' learning outcomes. European Journal of Engineering Education, 38(4), 359-369. https://doi.org/10.1080 /03043797.2013.766679.

Garrison, D., \& Arbaugh, J. B. (2007). Researching the community of inquiry framework: Review, issues, and future directions. The Internet and Higher Education, 10(3), 157-172. https://doi.org/10.1016/j. iheduc.2007.04.001. 
Garrison, D. R., \& Kanuka, H. (2004). Blended learning: Uncovering its transformative potential in higher education. The Internet and Higher Education, 7(2), 95-105.

Graham, C. R. (2006). Blended learning systems: Definition, current trends, and future directions. In C. J. Bonk \& C. R. Graham (Eds.), Handbook of blended learning: Global perspectives, Local Designs (pp. 321). San Francisco: Pfeiffer Publishing.

Hamilton, J., \& Tee, S. (2010). Smart utilization of tertiary instructional modes. Computers \& Education, 54(4), 1036-1053. https://doi.org/10.1016/j.compedu.2009.10.009.

Harrington, R., \& Loffredo, D. A. (2010). MBTI personality type and other factors that relate to preference for online versus face-to-face instruction. The Internet and Higher Education, 13(1), 89-95.

Holley, D., \& Oliver, M. (2010). Student engagement and blended learning: Portraits of risk. Computers \& Education, 54(3), 693-700.

Holsapple, C. W., \& Lee-Post, A. (2006). Defining, assessing, and promoting e-learning success: An information systems perspective. Decision Sciences Journal of Innovative Education, 4(1), 67-85.

Hoic-Bozic, N., Dlab, M. H., \& Mornar, V. (2016). Recommender system and web 2.0 tools to enhance a blended learning model. IEEE Transactions on Education, 59(1), 39-44.

Hsieh, \& Wu, M.-P. (2013). Exploring learning performance toward cognitive approaches of a virtual companion system in LINE app for m-learning. Eurasia Journal of Mathematics, Science \& Technology Education, 9(4), 337-346.

Hsu, L. L., \& Hsieh, S. I. (2011). Effects of a blended learning module on self-reported learning performances in baccalaureate nursing students. Journal of Advanced Nursing, 67, 2435-2444.

$\mathrm{Hu}$, P. J.-H., \& Hui, W. (2012). Examining the role of learning engagement in technology-mediated learning and its effects on learning effectiveness and satisfaction. Decision Support Systems, 53(4), 782-792. https://doi.org/10.1016/j.dss.2012.05.014.

Johnson, R. D., Hornik, S., \& Salas, E. (2008). An empirical examination of factors contributing to the creation of successful e-learning environments. International Journal of Human-Computer Studies, 66(5), 356-369.

Jonassen, D. H., \& Rohrer-Murphy, L. (1999). Activity theory as a framework for designing constructivist learning environments. Educational Technology Research and Development, 47(1), 61-79.

Junco, R., Heiberger, G., \& Loken, E. (2011). The effect of twitter on college student engagement and grades. Journal of Computer Assisted Learning, 27(2), 119-132. https://doi.org/10.1111/j.13652729.2010.00387.x.

Kahu, E. R. (2013). Framing student engagement in higher education. Studies in Higher Education, 38(5), $758-773$.

Khawaja, M. A., Prusty, G. B., Ford, R. A. J., Marcus, N., \& Russell, C. (2013). Can more become less? Effects of an intensive assessment environment on Students' learning performance. European Journal of Engineering Education, 38(6), 631-651.

Kim, J.-Y. (2012). A study on learners' perceptional typology and relationships among the learner's types, characteristics, and academic achievement in a blended e-education environment. Computers \& Education, 59(2), 304-315.

Kleinert, R., Heiermann, N., Plum, P. S., Wahba, R., Chang, D. H., Maus, M., et al. (2015). Web-based immersive virtual patient simulators: Positive effect on clinical reasoning in medical education. Journal of Medical Internet Research, 17(11). https://doi.org/10.2196/jmir.5035.

Kuh, G. D. (2009). The national survey of student engagement: Conceptual and empirical foundations. New Directions for Institutional Research, 2009(141), 5-20. https://doi.org/10.1002/ir.283.

Kumar, S. (2009). Undergraduate perceptions of the usefulness of web 2.0 in higher education: Survey development. In D. Remenyi (Ed.) Proceedings of the 8th European Conference on e-Learning (pp.308314). Italy.

Kumar, S. (2010). The net Generation's informal and educational use of new technologies. education, 16(1), 19-32.

Li, L.-Y., \& Chen, G.-D. (2009). A coursework support system for offering challenges and assistance by analyzing Students' web portfolios. Educational Technology \& Society, 12(2), 205-221.

Littlejohn, A., Beetham, H., \& McGill, L. (2012). Learning at the digital frontier: A review of digital literacies in theory and practice. Journal of Computer Assisted Learning, 28(6), 547-556. https://doi.org/10.1111 j.1365-2729.2011.00474.x.

McLoughlin, C., \& Lee, M. (2008). The three P's of pedagogy for the networked society: Personalization, participation, and productivity. International Journal of Teaching and Learning in Higher Education, 20(1), 10-27. 
McLoughlin, C., \& Lee, M. J. W. (2010). Personalised and self regulated learning in the web 2.0 era: International exemplars of innovative pedagogy using social software. Australasian Journal of Educational Technology, 26(1). https://doi.org/10.14742/ajet.1100

Michinov, N., \& Michinov, E. (2008). Face-to-face contact at the midpoint of an online collaboration: Its impact on the patterns of participation, interaction, affect, and behavior over time. Computers \& Education, 50(4), 1540-1557.

Moskal, P., Dziuban, C., \& Hartman, J. (2013). Blended learning: A dangerous idea? The Internet and Higher Education, 18, 15-23.

Muilenburg, L. Y., \& Berge, Z. L. (2005). Student barriers to online learning: A factor analytic study. Distance Education, 26(1), 29-48.

NCES. (2014). Table 303.25. Total fall enrollment in degree-granting postsecondary institutions, by control and level of institution: 1970 through 2014. https://nces.ed.gov/programs/digest/d15/tables/dt15_303.25. asp. Accessed 31 July 2017.

Oliver, R., Harper, B., Hedberg, J., Wills, S., \& Agostinho, S. (2002). Formalising the description of learning designs. In A. Goody, J. Herrington, \& M. Northcote (Eds.), Proceedings of the 2002 Annual International Conference of the Higher Education Research and Development Society of Australasia (HERDSA) (pp. 496-504). Perth: HERDSA.

Osguthorpe, R. T., \& Graham, C. R. (2003). Blended learning environments: Definitions and directions. The Quarterly Review of Distance Education, 4(3), 227-233.

Pascarella, E. T., \& Terenzini, P. T. (2005). How college affects students: A third decade of research. Volume 2. Indianapolis: Jossey-Bass, An Imprint of Wiley.

Phelps, R., Nhung, H. T. T., Graham, A., \& Geeves, R. (2012). But how do we learn? Talking to Vietnamese children about how they learn in and out of school. International Journal of Educational Research, vol, 53, 2289-2302.

Reese, S. A. (2015). Online learning environments in higher education: Connectivism vs. dissociation. Education and Information Technologies, 20(3), 579-588. https://doi.org/10.1007/s10639-013-9303-7.

Revere, L., \& Kovach, J. V. (2011). ONLINE TECHNOLOGIES FOR ENGAGED LEARNING A Meaningful Synthesis for Educators. Quarterly Review of Distance Education, 12(2).

Richardson, J. C., \& Ice, P. (2010). Investigating students' level of critical thinking across instructional strategies in online discussions. The Internet and Higher Education, 13(1), 52-59.

Robinson, C. C., \& Hullinger, H. (2008). New benchmarks in higher education: Student engagement in online learning. Journal of Education for Business, 84(2), 101-109.

Sanders, R. (2006). The "Imponderable Bloom": Reconsidering the Role of Technology in Education. Innovate: Journal of Online Education, 2(6). Retrieved January 15, 2020 from https://www. learntechlib.org/p/104331/.

Savery, J. R., \& Duffy, T. M. (1995). Problem based learning: An instructional model and its constructivist framework. Educational Technology, 35(5), 31-38.

UCF \& AASCU. (2017). Survey Instruments. https://blended.online.ucf.edu/evaluation-resources/surveyinstruments/. Accessed 31 July 2017.

Uğur, B., Akkoyunlu, B., \& Kurbanoğlu, S. (2011). Students' opinions on blended learning and its implementation in terms of their learning styles. Education and Information Technologies, 16(1), 5-23.

Vaughan, N. (2010). Student engagement and web 2.0: What's the connection? Education Canada, 50(2), 5255.

Venkatesh, V., Croteau, A.-M., \& Rabah, J. (2014). Perceptions of effectiveness of instructional uses of technology in higher education in an era of Web 2.0. Paper presented at 2014 47th Hawaii international Conference on the System Sciences (HICSS).

Wang, F., \& Hannafin, M. J. (2005). Design-based research and technology-enhanced learning environments. Educational Technology Research and Development, 53(4), 5-23.

Wu, J.-H., Tennyson, R. D., \& Hsia, T.-L. (2010). A study of student satisfaction in a blended e-learning system environment. Computers \& Education, 55(1), 155-164.

Yang, Y., Gamble, J., Hung, Y., \& Lin, T. (2014). An online adaptive learning environment for critical thinking-infused English literacy instruction. British Journal of Educational Technology, 45(4), 723-747.

Yen, J.-C., \& Lee, C.-Y. (2011). Exploring problem solving patterns and their impact on learning achievement in a blended learning environment. Computers \& Education, 56(1), 138-145.

Young, S., \& Bruce, M. A. (2011). Classroom community and student engagement in online courses. Journal of Online Learning and Teaching; Long Beach, 7(2), 219.

Publisher's note Springer Nature remains neutral with regard to jurisdictional claims in published maps and institutional affiliations. 


\section{Affiliations}

Frederique Bouilheres ${ }^{1} \cdot$ Le Thi Viet Ha Le ${ }^{2} \cdot$ Scott McDonald ${ }^{2} \cdot$ Clara Nkhoma $^{2}$. Lilibeth Jandug-Montera ${ }^{2}$

Le Thi Viet Ha Le

ha.lethiviet@rmit.edu.vn

Scott McDonald

scott.mcdonald@rmit.edu.vn

Clara Nkhoma

clara.nkhoma@rmit.edu.vn

Lilibeth Jandug-Montera

lilibeth.jandug@rmit.edu.vn

1 Jubilee Campus, University of Nottingham, Wollaton Road, Nottingham, UK

2 RMIT University Vietnam, 702 Nguyen Van Linh Street, District 7, Ho Chi Minh City, Vietnam 